\title{
ПІДХІД ДО ВИРІШЕННЯ ЗАДАЧІ ОПЕРАТИВНОГО УПРАВЛІННЯ В ГНУЧКИХ ВИРОБНИЧИХ СИСТЕМАХ В УМОВАХ НЕВИЗНАЧЕНОСТЕЙ
}

\begin{abstract}
Анотація: в статті розглядається проблема оперативного управління в гнучких виробничих системах в умовах невизначеностей, що пов'язані з перебоями в роботі інформаційної підсистеми гнучких виробничих систем. В роботі приведена класифікація проблем, що виникають в зазначених умовах, формуючи невизначеність, а також запропонована стратегія реакції системи оперативного управління на кожен тип таких проблем, описана у вигляді продукційної моделі.

Ключові слова: дані, діагностування, відмова, надійність, інформація, продукційна модель
\end{abstract}

\section{Вступ}

В роботі гнучких виробничих систем (ГВС) неминуче виникають нештатні ситуації. У випадку реалізації системи оперативного управління (СОУ) ГВС з синхронною імітаційною моделлю, оперативне управління грунтуеться на імітаційному моделюванні ГВС в режимі реального часу. Така модель повністю залежить від інформації, що надходить від інформаційної підсистеми (IП) ГВС, компонентами якої е система датчиків та засобів передачі даних до імітаційної моделі, і вихід з ладу будь-якого з компонентів системи може спринити розсинхронізацію реальної виробничої системи та iї моделі. Таким чином, варто зазначити, що всі датчики IП ГВС можна розділити на дві групи:

1. ті, які порушують процес оперативного управління і змушують СОУ змінювати маршрути матеріальних потоків між ГВМ

2. ті, які не порушують вказаний процес

У випадку, коли з ладу вийшов датчик з другої групи, одним із запропонованих способів вирішення вищезазначеної проблеми $є$ застосування додаткової синхронної моделі виробництва з функцією корекції недоотриманої інформації з ІП ГВС (рис. 1), яка включається в роботу у випадку виникнення нештатної ситуації і з певною затримкою посилає коригуючі сигнали СОУ, що дозволяють відновлювати втрачену інформацію, необхідну для нормального функціонування СОУ з синхронною імітаційною моделлю [1].

Власне факт недоотримання чи невчасного отримання необхідної інформації у зв'язку з виходом з ладу чи перебоями в роботі датчиків чи каналів передачі інформації з датчиків окремих гнучких виробничих модулів (ГВМ), автоматизованих транспортних

(c) P.I. Дзінько, О.І. Лісовиченко, 2015 


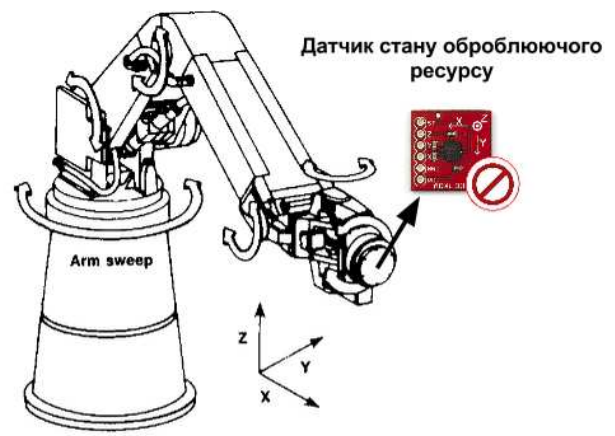

a)

Датчик підрахунку деталей

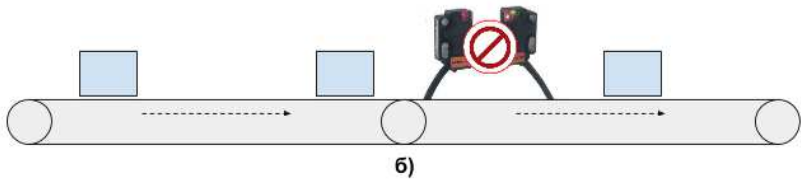

Рис. 1 - а) Вихід з ладу датчика стану оброблюючого ресурсу; б) вихід з ладу датчика підрахунку деталей, що пройшли через точку на конвеєрі.

модулів (АТМ), та інших компонентів ГВС, є причиною виникнення невизначеності для СОУ ГВС.

Суть невизначеності полягає в тому, що факт невчасного отримання інформації СОУ ГВС не обов'язково означае вихід з ладу обладнання, що належить IП ГВС, а й іншого обладнання, в тому числі і оброблюючих ресурсів (рис. 2).

\section{Постановка задачі}

Розглядається СОУ ГВС з синхронною імітаційною моделлю.

Необхідно розробити математичну модель для вирішення задачі прийняття рішення про стратегію генерації коригуючих впливів додаткової синхронної моделі (ДСМ) на імітаційну модель СОУ ГВС, яка повинна включатись в роботу виключно в тих випадках, коли нормальний режим їі функціонування порушений.

Оскільки, характер проблеми, як було зазначено у вступі до статті, $е$ не детермінованим, а стохастичним, в якості вхідних даних до задачі слід використати стохастичні показники технологічного обладнання (ТО), а саме параметри надійності гнучких виробничих модулів, сенсорів, та фрізичних каналів зв'язку ІП ГВС. 


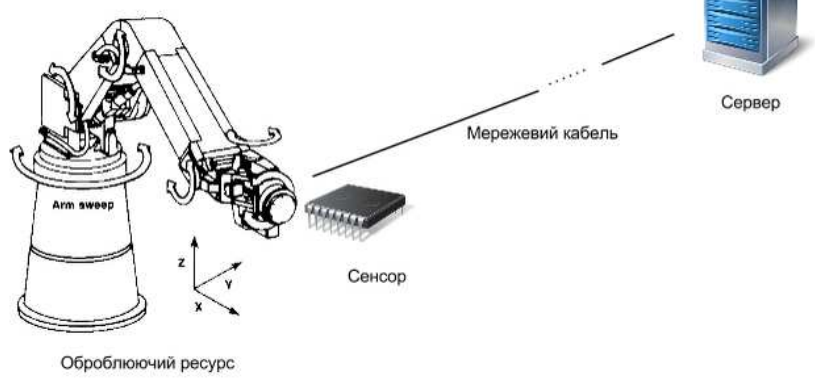

Рис. 2 - Факт неотримання даних на сервері з сенсору може означати, що з ладу вийшов або оброблюючий ресурс, або сенсор, або мережевий кабель.

\section{Параметри надійності технологічного обладнання}

Для розв'язання поставленої задачі слід провести визначення наявності нештатної ситуації, що могла виникнути на технологічному обладнанні ГВС, тобто потрібно обчислити ймовірність виходу з ладу конкретного ТО, інформацію про яке в конкретний момент часу опрацьовуе імітаційна модель в ситуації, коли пов'язаний з моніторингом за цим ТО датчик виходить з ладу (рис. 2).

Для визначення ймовірності виходу з ладу технологічного обладнання $F(t)=P(T \leq t)$ (де $t-$ час, за який відбувається показник надійності, $T$ - момент часу, в який виникає відмова) в кожен конкретний момент часу, потрібно знайти наступне відношення:

$$
\left.F(t)=\left(t-T_{p}\right) / T_{c p}\right)
$$

де $T_{p}$ - час виникнення попередньої відмови, $T_{c p}$ - середній час напрацювання на відмову. Необхідними вхідними даними для визначення цієї величини є:

1. Період роботи ТО: припрацювання, нормальна експлуатація, старіння та знос.

2. Час виникнення попередньої відмови .

3. Параметри законів інтенсивності відмов $\lambda(t)$ Вейбулла $\left(\lambda_{0}-\right.$ масштаб, $k$ - асиметрія), та Релея ( $r$-параметр розподілу) для кожного ТО виробництва.

Тому, $T_{c p}$, в залежності від періоду роботи технологічного обладання, визначається як $T_{c p}=\Gamma(1 / k+1) / \lambda_{0}^{1 / k}$, де $\Gamma$ - гамма-функція, для періоду припрацювання, $T_{c p}=1 / \lambda_{0}$ для періоду нормальної експлуатації, та $T_{c p}=1.253 r$ для періоду старіння та зносу [2]. 
Знаючи значення $T_{p}$ для кожного ТО, а також, підставивши одну з формул визначення $T_{c} p$ в фрормулу (1), отримаємо ймовірність виходу з ладу конкретного технологічного обладнання в заданий момент часу.

\section{Формування стратегії управляючих впливів ДСМ}

Основою роботи ДСМ є формування управляючих впливів на імітаційну модель СОУ з ціллю уникнення явища розсинхронізації виробництва та моделі виробництва в зв'язку з виходом з ладу обладнання ІП ГВС (рис. 3).

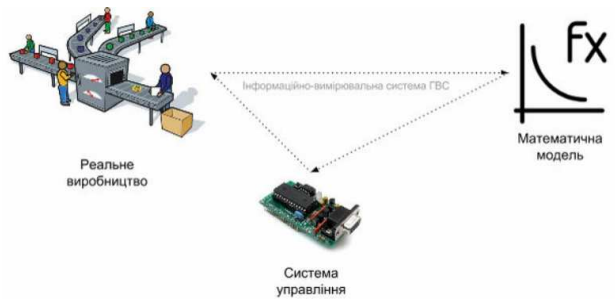

Рис. 3 - Взаємозалежність залежність моделі виробництва та реального виробництва

Оскільки, при виникненні збоїв в роботі ІП ГВС, інформація про стан конкретної одиниці ТО, що моніториться, повністю або частково відсутня, необхідно скористатись ймовірнісними характеристиками обладання в певний конкретний момент часу, а також інформацією про наявність обладнання контролю якості безпосередньо на виході продукції з ТО.

Оскільки, імітаційна система є дискретною, на підставі існуючої інформації, можна побудувати наступну систему прийняття рішень на базі апарату продукційних правил для кожного конкретного ТО (рис. 1).

Варто зазначити, також, таку величину як критична ймовірність відмови (рис. 4), яку визначимо як максимальне допустиме значення ймовірності виходу з ладу ТО в конкретний момент часу, що формується як експертна оцінка в залежності від таких параметрів як ціна простою виробництва та ціна випуску браку, а також інших фракторів, що визначаються експертом для кожного конкретного ТО та кожного конкретного виробництва.

\section{Висновки}

Вихід з ладу обладнання IП ГВС породжуе таку невизначеність для СОУ ГВС з імітаційною моделлю як відсутність інформації про стан ТО, що моніториться. Оскільки, отримати детерміновану інформацію про стан технологічного обладнання в такому випадку 


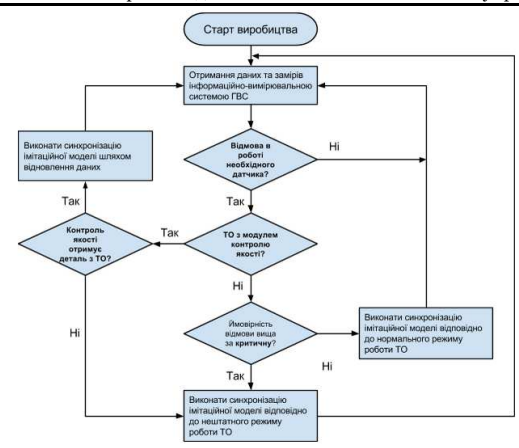

Рис. 4 - Продукційні правила прийняття рішення генерації коригуючих впливів ДСМ.

не $е$ можливим, було прийнято рішення оцінювати стан ТО стохастичними параметрами виходячи з теорії надійності технічних систем.

В якості продовдження досліджень спрямованих на побудову стійкої до відмов ІП ГВС системи оперативного управління ГВС з імітаційною моделлю, були виконані кроки до ідентифікації вказаної невизначеності, на базі яких здійснено фрормування продукційної моделі правил формування стратегії генерації коригуючих впливів ДСМ на основну імітаційну модель виробництва.

В якості обмежень по прийнятній ймовірності виходу з ладу технологічного обладнання, за якої можлива робота ДСМ (що вміе відновлювати втрачені дані IП ГВС), був застосований такий показник як критична ймовірність відмови, що формуеться як експертна оцінка в залежності від параметрів виробництва.

\section{Список використаних джерел}

1. Дзінько Р.I Система оперативного контролю виробництва з дублюючою синхронною моделлю / P.I. Дзінько, О.І. Лісовиченко // Міжвідомчий науково-технічний збірник "Адаптивні системи автоматичного управління”. - 2013. - № 1(22).

2. Васілевський О.М. Нормування показників надійності технічних засобів / Васілевський О.М., Поджаренко В.О. // Вінниця: ВНТУ, 2010. - 129 c.

3. Дзінько Р.І. Підвищення відмовостійкості функціонування гнучких виробничих систем за допомогою прихованих марківських моделей / P.I. Дзінько, О.I. Лісовиченко // Міжвідомчий науково-технічний збірник "Адаптивні системи автоматичного управління”. - 2013. - № 2(23). 